LA WRENCE LIWEAMCAE NATIONAL LABOAATOAY

Synthesis of Novel Extended Phases of Molecular Solids at High Pressures and Temperatures

H. Cynn, W. Evans, C.-S. Yoo

Lawrence Livermore National Laboratory,

University of California,

Livermore California 94551, USA

Annual Report 2003, Spring-8 
This document was prepared as an account of work sponsored by an agency of the United States Government. Neither the United States Government nor the University of California nor any of their employees, makes any warranty, express or implied, or assumes any legal liability or responsibility for the accuracy, completeness, or usefulness of any information, apparatus, product, or process disclosed, or represents that its use would not infringe privately owned rights. Reference herein to any specific commercial product, process, or service by trade name, trademark, manufacturer, or otherwise, does not necessarily constitute or imply its endorsement, recommendation, or favoring by the United States Government or the University of California. The views and opinions of authors expressed herein do not necessarily state or reflect those of the United States Government or the University of California, and shall not be used for advertising or product endorsement purposes.

This work was performed under the auspices of the U.S. Department of Energy by University of California, Lawrence Livermore National Laboratory under Contract W-7405-Eng-48. 


\title{
Synthesis of Novel Extended Phases of Molecular Solids at High Pressures and Temperatures
}

\author{
Hyunchae Cynn, William Evans, and Choong-Shik Yoo (9561) \\ Lawrence Livermore National Laboratory, University of California, \\ Livermore California 94551, USA
}

This study is for in-situ investigation of chemical bonding and molecular structure of low z-elements and simple molecular solids at high pressures and temperatures using $3^{\text {rd }}$ generation synchrotron x-ray diffraction. To understand the contribution of the empty $\mathrm{d}$-electron orbital of $\mathrm{Mg}$ in relation to the formation of molecular solids like $\mathrm{MgO}$, which is one of the important Earth lower mantle materials and $\mathrm{MgB}_{2}$, which has recently been the focus of intense superconducting material research, we have performed double-sided laser heating experiments using a diamond anvil cell (DAC). Understanding the structural stability and the formation of the above $\mathrm{Mg}$ compounds requires studying $\mathrm{Mg}$ itself as well as the relevant compounds.

BL10XU at the SPring- 8 was used to study phase stability and make accurate equation of state (EOS) determinations of $\mathrm{Mg}$ coupled with external heating and the doublesided laser heating technique. Monochromatic $\mathrm{x}$-ray at $30 \mathrm{keV}(0.4135 \AA)$ was focused to about $40 \mu \mathrm{m}$ at the sample and the diffracted $\mathrm{x}$-ray were recorded using a high-resolution image plate $(3000 \times 3000$ pixels with a $0.1 \mathrm{~mm}$ resolution per pixel).

EOS parameters for hcp and bcc Mg were determined by fitting to a Birch-Murnaghan equation. An isothermal compression of $\mathrm{Mg}$ at $300 \mathrm{~K}$ up to $100 \mathrm{GPa}$ provides EOS parameters $\left(\mathrm{B}_{0}, \mathrm{~B}_{0}\right.$, , and $\left.\mathrm{V}_{0}\right)$ comparable for both hep and bcc phases, which is similar to the cases for hcp and fcc phases measured in cobalt and xenon. Similar EOS parameters for both low and high pressure phases with a very small or no measurable volume discontinuity at the phase transition pressure suggests that the hcp-bcc structural transition of $\mathrm{Mg}$ may be driven by a stacking fault due to a shear instability as seen in xenon and cobalt. Compared to the recent estimation determined using a large volume press [1], our $\mathrm{B}_{0}$ is smaller by more than $10 \%$ suggesting that the difference may be due to non-hydrostatic conditions. The phase boundary of $\mathrm{Mg}$ up to $650 \mathrm{~K}$ was determined using external resistive heating in air. The results show a noticeable hysteresis during forward and backward transitions. The initial negative slope of the phase boundary agrees very well with the value predicted by theory[2].

Double-side laser heating at several pressures below $20 \mathrm{GPa}$ (Fig. 1) with simultaneous in-situ $\mathrm{x}$-ray diffraction indicates that hcp is the dominant stable phase and a double hexagonal close packed structure (dhcp) is not seen at high temperatures and high pressures, unlike the observations of recent studies of $\mathrm{Mg}$ using a large volume press, claiming dhep below $20 \mathrm{GPa}$ between 1350 and $1050 \mathrm{~K}$. We suggest that the dhep may appear as nonequillibrium phase induced by shear stress.

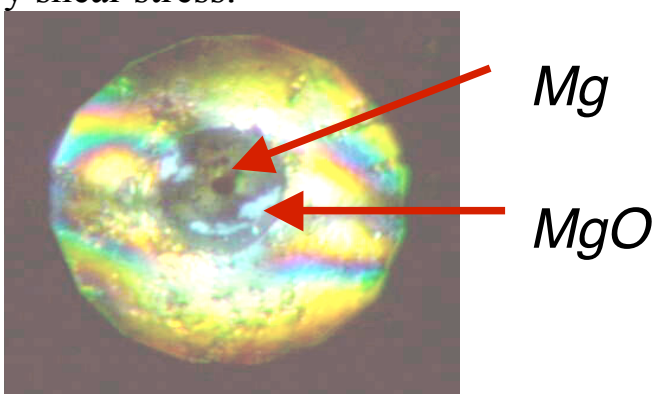

Fig. 1. Photomicrograph of $\mathrm{Mg}$ sample surrounded by $\mathrm{MgO}$ under pressure. Note the laser spot in the middle of the $\mathrm{Mg}$ sample indicating high temperature near melting. The entire culet size is $0.3 \mathrm{~mm}$ in diameter.

[1] Errandonea D, Meng Y, Hausermann D, and Uchida T (2003) J. Phys. Condens. Matter 151277.

[2] Moriarty JA and Althoff JD (1995) Phys. Rev. B 515609.

This work was performed under the auspices of the U.S. DOE by the Univ. of California, LLNL under contract No. W-7405Eng-48. 